\title{
Bending and Compression Properties of ABS and PET Structural Materials Printed Using FDM Technology
}

\author{
Stefan Szczepanik $k^{\mathrm{a}}$, Piotr Bednarczyk $\mathrm{k}^{\mathrm{a}, *}$ \\ ${ }^{a}$ AGH University of Science and Technology, Faculty of Metals Engineering and Industrial Computer Science, Mickiewicza 30, 30-059 Krakow, \\ Poland \\ *e-mail: pbednar@agh.edu.pl
}

Received: 22 February 2017/Accepted: 7 July 2017/Published online: 28 July 2017

This article is published with open access at AGH University of Science and Technology Press

\begin{abstract}
The bend and compression mechanical properties of 3D-printed polyethylene terephthalate (PET) and acrylonitrile butadiene styrene (ABS) rectangular and cylindrical specimens (fully-dense and with circular, hexagonal, and rectangular perforations) are presented. In three-point bending, fully-dense PET flexural strength was $69 \mathrm{MPa}$, yield stress was 48.9 MPa, and yield stress from compression was 31.4 MPa. For ABS, these values were 59, 41.7, and 51.2 MPa, respectively - not significantly different from those of polymers manufactured by common techniques. Whereas perforation reduced density, the strength values were significantly lower, decreased for the circular perforation to a value of $20 \%$ strength for the fully-dense specimen. Specific strengths dropped quite significantly for the specimens tested in bending, whereas they did not differ significantly when tested by compression.
\end{abstract}

\section{Keywords:}

3D printing, PET, ABS, three-points bending, compression test

\section{INTRODUCTION}

3D-printing technologies at present produce prototype elements, but also small series (e.g., automotive and aeronautical) and for individual applications (e.g., in medicine) [1-4]. Then, additive manufacturing is used as an intraoperative surgical guide for models of surgical tasks as well as in tissue and regenerative engineering $[5,6]$. Figure 1 shows our model for planning and preparing the operation for a skull injury. At first, skull models were generated based on Computed Tomography (CT). The next step was designing the implant model using open-source software and comparing implant accuracy to the patient skull model. This model was made using the printing technique known as FDM (Fused Deposition Modeling) of polyethylene terephthalate (PET) polymer material.

FDM is one of the simplest and frequently used 3D printing technologies for thermoplastics and polymers reinforced by carbon fibers or metal powders. Increasingly, the products obtained by this technology are used as structural materials [7]. Hence, it is necessary to investigate their mechanical properties and dimensional tolerances, which has already been the subject of much research [8-10]. In this project, we focus on the last of these parameters: trying to consider the effects of discontinuities in printed specimens made from PET and acrylonitrile butadiene styrene (ABS) filaments. a)

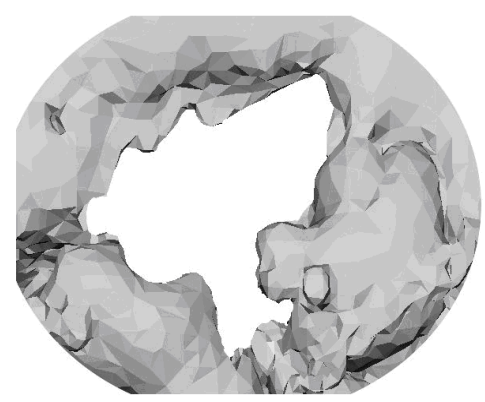

b)

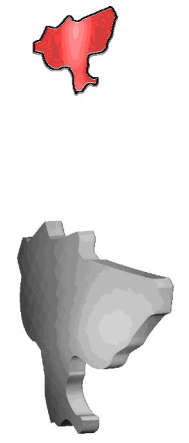

c)

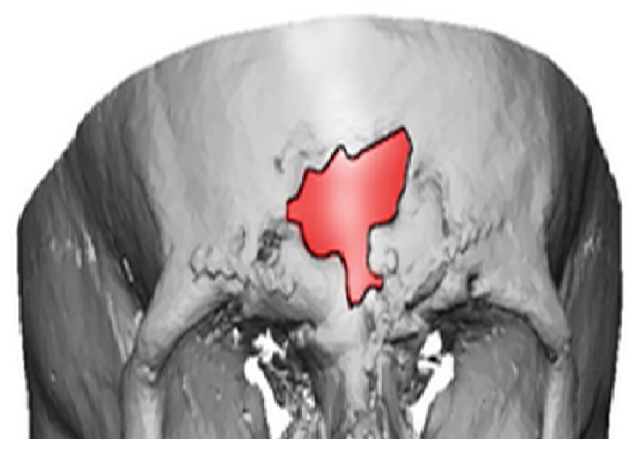

Fig. 1. Design of the implant model: a) CAD image of bone loss from CT; b) model of implant; c) CAD model of implant in the skull 
The aim is to determine the properties of low-density structural materials and investigate the influence of the shape and construction, taking into account the presence of perforations. The use of perforated products is one of the ways to reduce the weight of a structure without incurring a significant loss of mechanical properties. For example, in maxillofacial surgery, the presence of holes is required to allow the jaw implant to be fixed. This study will enable us to determine the applicability of the products obtained from these 3D-printed materials, especially PET for medical applications.

\section{EXPERIMENTAL PROCEDURES}

Specimens with polygonal, circular, and square perforations were designed. Various shapes of the perforation forced different directions of the flow of material during printing, so the mechanical properties were affected. Three types of perforation were designed using SolidWorks 2015 and Fill Pattern operation (Fig. 2):

- Type 1: polygonal shape, 6 sides, circle diameter $2 \mathrm{~mm}$, angle of rotation $30^{\circ}$, loop spacing $5.6 \mathrm{~mm}$, pattern direction $0^{\circ}$, number of instance 41 ,

- Type 2: square shape, diameter $3 \mathrm{~mm}$, angle of rotation $0^{\circ}$, loop spacing $5.4 \mathrm{~mm}$, pattern direction $0^{\circ}$, number of instance 39,

- Type 3: circular shape, diameter $4.25 \mathrm{~mm}$, angle of rotation $0^{\circ}$, loop spacing $5 \mathrm{~mm}$, pattern direction $0^{\circ}$, number of instance 45 .

a)

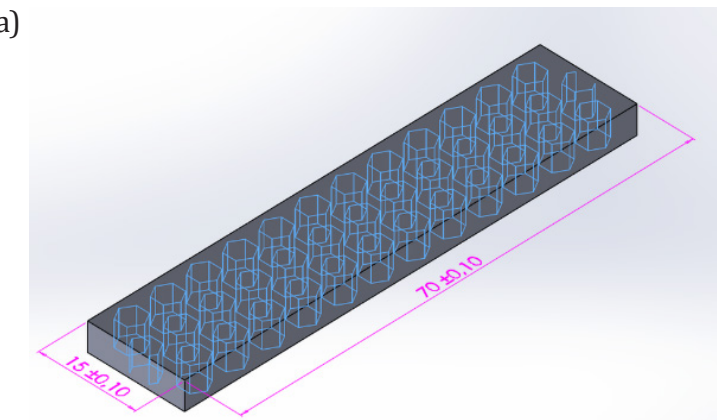

b)

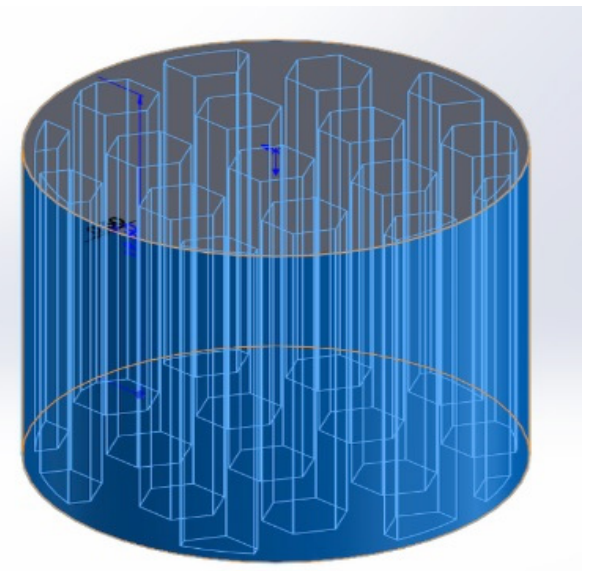

Fig. 2. Designed structure with polygonal perforation: a) bending test; b) compression test
Figure 2 shows specimens designed with polygonal perforation. Specimens were printed on a 3D Kreator Motion printer. Both PET and ABS materials were printed at a temperature of $245^{\circ} \mathrm{C}$ with a speed of $35 \mathrm{~mm} / \mathrm{s}$. For the bending test, the cuboidal specimen dimensions were $15 \times 70 \mathrm{~mm}$ with a thickness of $4 \mathrm{~mm}$. For the compression tests, specimens with a diameter of $20 \mathrm{~mm}$ and height of $20 \mathrm{~mm}$ were used. The printed specimens from ABS are shown in Figure 3.

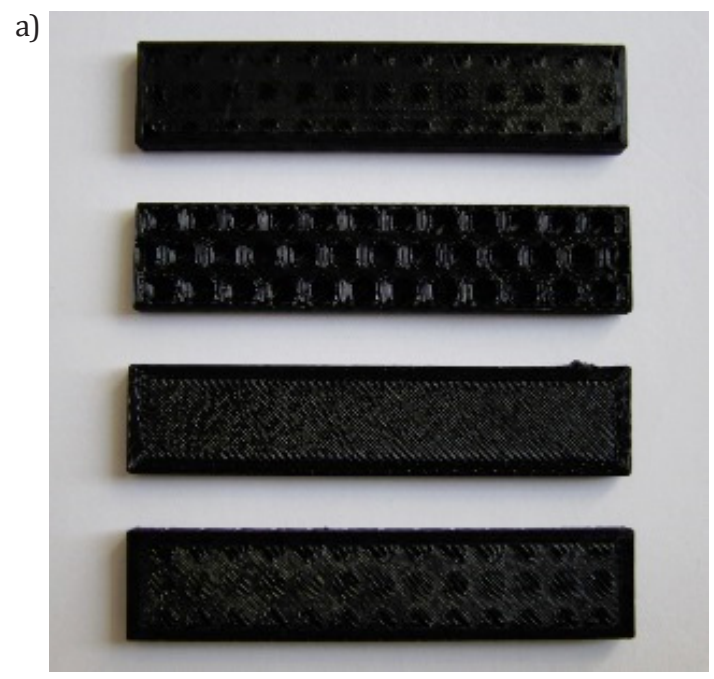

b)

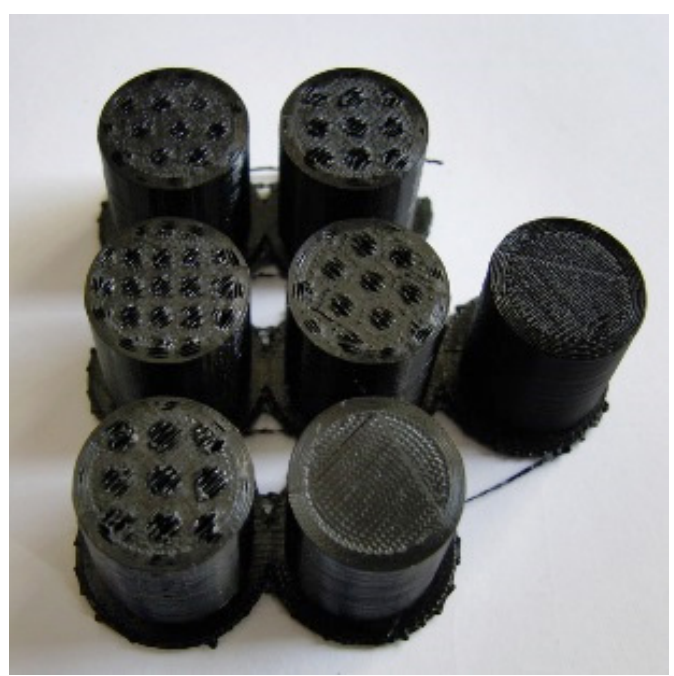

Fig. 3. ABS specimens printed for: a) bending; b) compression tests

Three-point bending tests on a span of $40 \mathrm{~mm}$ were carried out on an universal testing machine (INSTRON 1196) with a speed of $1 \mathrm{~mm} / \mathrm{min}$. From the measured force vs. displacement data during bending, the a yield stress of $\sigma_{b 0.2}$, bending strength of $\sigma_{b}$, ratio of yield to bending strength, and maximal strain for cracking $\varepsilon_{c}$ were calculated. The properties were compared to fullydense specimens to calculate the specific strength.

The compression test was carried out on an INSTRON 4502 with a ram speed of $2 \mathrm{~mm} / \mathrm{min}$. Yield compression stress $\sigma_{c 0.2}$ and specific yield stress $\sigma_{c 0.2 / p}$ of the specimens were calculated. 


\section{RESULTS}

\subsection{Three-point bending test}

Results from the bending tests are summarized in Table 1 , and the bending-stress curves are shown in Figures 4a and $4 \mathrm{~b}$. The structure of the specimens strongly affected the bending strength of the materials.

Table 1

Results of bending tests

\begin{tabular}{cccccccc}
\hline Material & $\begin{array}{c}\text { Structure } \\
\text { type }\end{array}$ & $\begin{array}{c}\boldsymbol{\sigma}_{\mathbf{0 . 2}}, \\
\mathbf{M P a}\end{array}$ & $\begin{array}{c}\boldsymbol{\sigma}_{b,} \\
\mathbf{M P a}\end{array}$ & $\begin{array}{c}\boldsymbol{\varepsilon}_{c,} \\
\mathbf{\%}\end{array}$ & $\begin{array}{c}\boldsymbol{\rho}, \\
\mathbf{g} / \mathbf{c m}^{3}\end{array}$ & $\boldsymbol{\sigma}_{b 0.2} / \boldsymbol{\rho}$ & $\boldsymbol{\sigma}_{b} / \boldsymbol{\rho}$ \\
\hline \multirow{4}{*}{ ABS } & fully-dense & 41.7 & 54.2 & 2.58 & 0.92 & 45.4 & 59 \\
\cline { 2 - 8 } & 1 polygonal & 19.1 & 24.8 & 1.25 & 0.67 & 28.6 & 37 \\
\cline { 2 - 8 } & 2 square & 15.6 & 19.2 & 1.6 & 0.59 & 26.4 & 32.5 \\
\cline { 2 - 8 } & 3 circular & 8.1 & 8.7 & 1.13 & 0.46 & 17.7 & 19.1 \\
\hline \multirow{4}{*}{ PET } & fully-dense & 48.9 & 69 & 2.22 & 1.13 & 43.3 & 61.1 \\
\cline { 2 - 8 } & 1 polygonal & 29.2 & 33 & 1.91 & 0.8 & 32.7 & 41.3 \\
\cline { 2 - 8 } & 2 square & 36.9 & 37.5 & 1.1 & 0.82 & 45 & 45.7 \\
\cline { 2 - 8 } & 3 circular & 7.5 & 10.5 & 1.58 & 0.55 & 13.7 & 19.2
\end{tabular}

a)

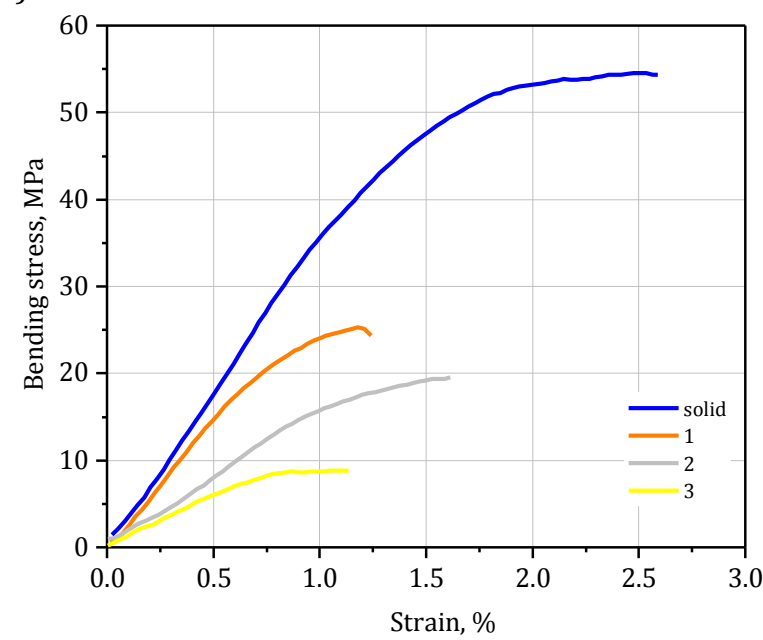

b)

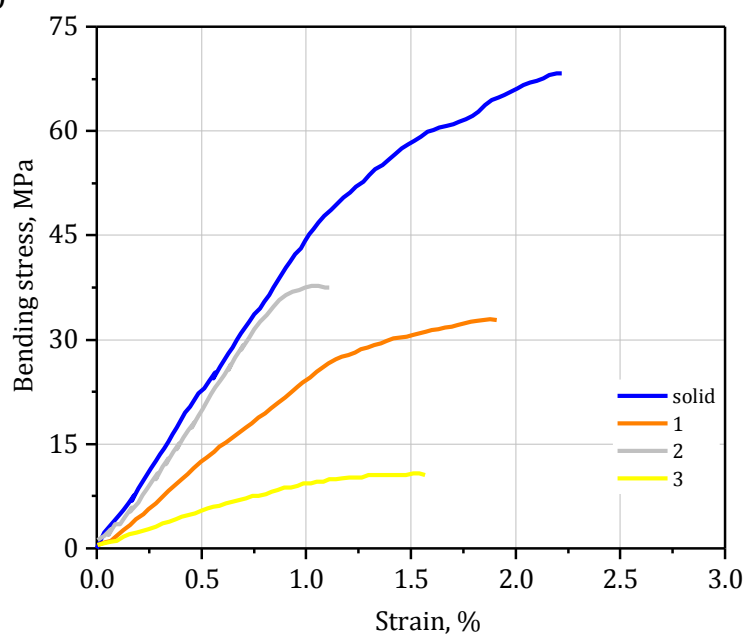

Fig. 4. Bending stress vs strain: a) ABS; b) PET

\subsection{Compression tests}

Results from the compression tests are summarized in Table 2, and the compression stress-strain curves are shown in Figure 5. Compression results show that the perforation type of a specimen's structure (holes) decreases the strength differently; however, specific strength values oscillate at the same level. Hence, the values of specific strength range from 22.4 to $26.4 \mathrm{MPa}$ for the ABS material, and 26.5-32.9 MPa for the PET material.

Table 2

Compression test results

\begin{tabular}{cccc}
\hline Material & $\begin{array}{c}\text { Structure } \\
\text { type }\end{array}$ & $\begin{array}{c}\boldsymbol{\sigma}_{\text {c0.2' }} \\
\text { MPa }\end{array}$ & $\boldsymbol{\sigma}_{c 0.2} / \boldsymbol{\rho}$ \\
\hline \multirow{4}{*}{ ABS } & fully-dense & 51.2 & 26.4 \\
\cline { 2 - 4 } & 1 polygonal & 30.3 & 26.3 \\
\cline { 2 - 4 } & 2 square & 22.7 & 23.1 \\
\cline { 2 - 4 } & 3 circular & 26.7 & 22.4 \\
\hline \multirow{3}{*}{ PET } & fully-dense & 31.4 & 26.5 \\
\cline { 2 - 4 } & 1 polygonal & 21.1 & 30.1 \\
\cline { 2 - 4 } & 2 square & 23 & 32.1 \\
\cline { 2 - 4 } & 3 circular & 20.3 & 32.9 \\
\hline
\end{tabular}

a)

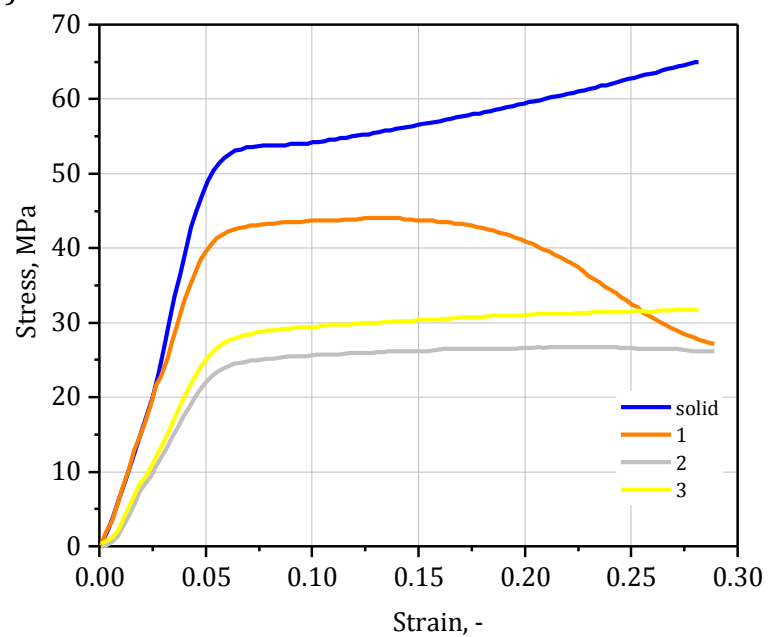

b)

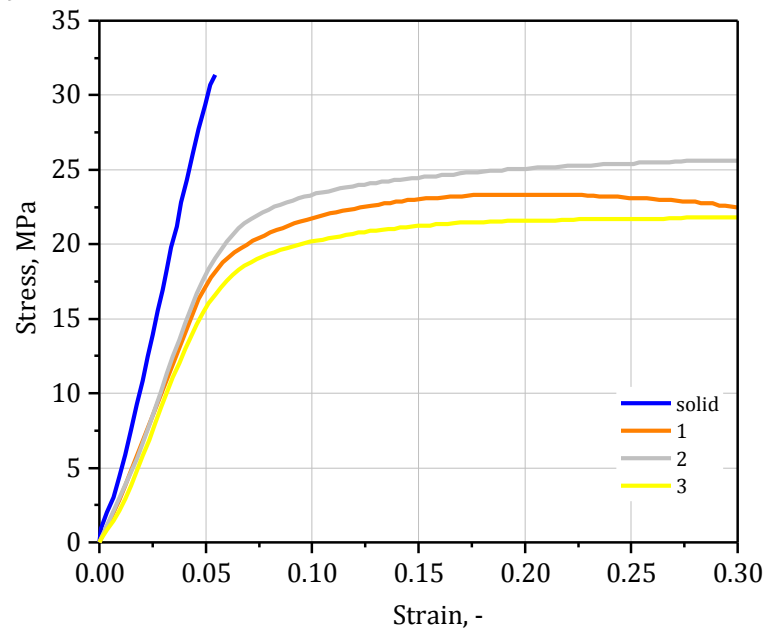

Fig. 5. True stress - true strain compression curve: a) ABS; b) PET 
The ABS specimens after tests are shown in Figure 6.

a)

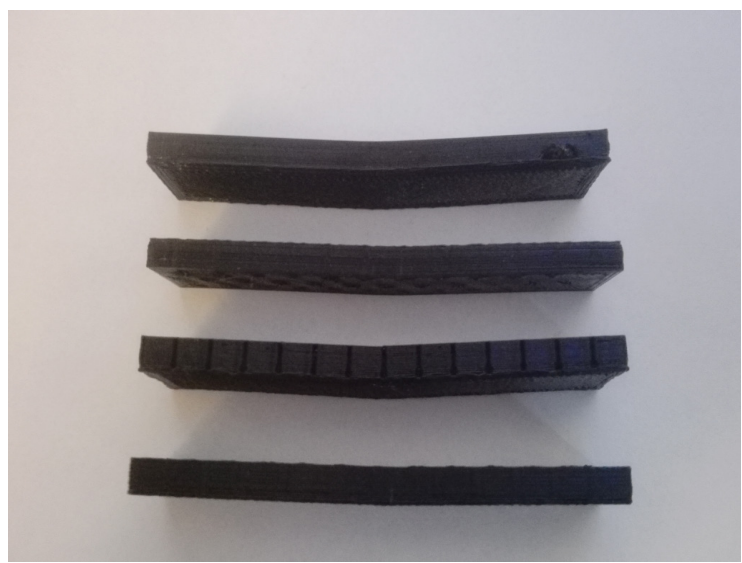

b)

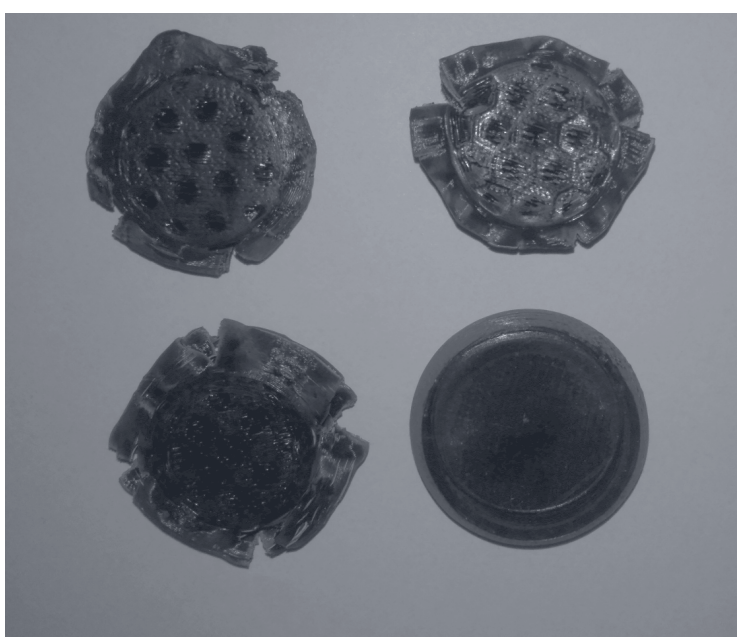

Fig. 6. ABS specimens after a) bending test; b) compression test

\section{DISCUSSION}

The structure of the specimens strongly affected the bending and compression strengths as well as the critical strains of the ABS and PET materials. In comparison with fullydense materials, the bending strength always decreased: $54 \%$ for PET specimen Type 1, 64\% for Type 2, and $83 \%$ for Type 3. In fully-dense ABS, the deformation was $2.58 \%$ - almost twice that of the weakest material with a Type 3 structure. For the PET material, the lowest critical strain was observed for the Type 2 structure. Specific properties of PET materials in bending were as follows: yield stress 43.3 to $13.7 \mathrm{MPa} \cdot \mathrm{cm}^{3} / \mathrm{g}$, strength 61.1 to $19.2 \mathrm{MPa} \cdot \mathrm{cm}^{3} / \mathrm{g}$, and for $\mathrm{ABS}, 45.4$ to $17.7 \mathrm{MPa} \cdot \mathrm{cm}^{3} / \mathrm{g}$, 59 to $19.1 \mathrm{MPa} \cdot \mathrm{cm}^{3} / \mathrm{g}$, respectively. The density of the PET specimens was within a range of 1.13 to $0.55 \mathrm{~g} / \mathrm{cm}^{3}$, and ABS materials -0.92 to $0.46 \mathrm{~g} / \mathrm{cm}^{3}$. The compression yield stress for ABS material was within a range of 51.2 to $26.7 \mathrm{MPa}$, and for PET - 31.4-20.3 MPa; however, specific yield strength was within a range of 26.4 to $22.4 \mathrm{MPa} \cdot \mathrm{cm}^{3} / \mathrm{g}$ and 26.5 to $32.9 \mathrm{MPa} \cdot \mathrm{cm}^{3} / \mathrm{g}$, respectively.

\section{CONCLUSIONS}

Using a low-cost printer, structural models from ABS and PET filaments can be manufactured. The products have satisfactory mechanical properties for manufacturing 3D lightweight models for visualization and analysis. The strength properties are sufficient to print structural models. The specific properties in compression are comparable for the ABS and PET materials. Discontinuities adversely affect the investigated properties. It is necessary to optimize printing parameters such as temperature, layer thickness, and deposition speed to optimize the mechanical properties of the printed products. It is possible to manufacture virtual and prototype models without expensive dies and machines. The printing process is susceptible to many factors, like ambient temperature and moisture. To obtain good mechanical properties in the printed products, these parameters should be stable. Deposition of the filament is an important factor, and it can affect structural stability. This effect results from different shrinkage anisotropy of the material.

\section{REFERENCES}

[1] Tenerowicz M., Rzadkosz S., Żak P., Kranc M. (2013). Komputerowe wspomaganie odlewnictwa artystycznego. Archives of Foundry Engineering, 13 (spec. iss. 3), 171-174.

[2] Jarco A., Rzadkosz S., Krokosz J., Pabiś R., Gil A., Czekaj E., Modlnicki S., Ćwiklak R. (2012). Studium technologiczno-konstrukcyjne wykorzystania techniki szybkiego prototypowania do wykonania odlewu artystycznego medalu 65-lecia Instytutu Odlewnictwa w Krakowie. Prace Instytutu Odlewnictwa, 1(52), 55-70, doi:10/7356/iod.2012.04

[3] Budzik G., Budzik W., Cygnar M., Janisz, K. (2009). Możliwość zastosowania szybkiego prototypowania w procesie projektowania i wytwarzania elementów pojazdów samochodowych. Problemy eksploatacji, 1(72), 7-16.

[4] Werkheiser N. (2015). 3D printing in space technology demonstration. 2015 National Space \& Missile Materials Symposium NSMMS. 22-25 June. Chantilly, USA.

[5] Cykowska-Błasiak M., Ozga P. (2015). Wydruk 3D jako narzędzie do planowania zabiegów ortopedycznych. Budownictwo i Architektura, 1(14), 15-23.

[6] Kaye R., Goldstein T., Zeltsman D., Grande D.A., Smith L.P. (2016). Three dimensional printing: A review on the utility within medicine and otolaryngology. International Journal of Pediatric Otorhinolaryngology, 89, 145-148.

[7] Wohlers T., Caffrey, T., Campbell I. (2016). Wohlers Report 2016. 3D printing and additive manufacturing state of the industry: annual worldwide progress report. Wohlers Associates, Fort Collins, USA.

[8] Wang J., Xie H., Weng Z., Senthil T., Wu L. (2016). A novel approach to improve mechanical properties of parts fabricated by fused deposition modeling. Materials and Design, 105, 152-159.

[9] Weng Z., Wang J., Senthil T., Wu L. (2016). Mechanical and thermal properties of ABS/montmorillonite nanocomposites for fused deposition modeling 3D printing. Materials and Design, 102, 276-283.

[10] Lieneke T., Denzer V., Adam G. A. O., Zimmer D. (2016). Dimensional tolerances for additive manufacturing: Experimental investigation for Fused Deposition Modeling. Procedia CIRP, 43, 286-291. 